\title{
Heated Tobacco Products: A Review of Current Knowledge and Initial Assessments
}

\author{
Nadja Mallock*, Elke Pieper, Christoph Hutzler, Frank Henkler-Stephani and Andreas Luch \\ Department of Chemical and Product Safety, German Federal Institute for Risk Assessment (BfR), Berlin, Germany
}

The health risks of tobacco smoking have been documented in numerous studies and smoking rates have declined in developed countries over the last 50 years. Today, we know that cigarette smoking is the major cause of preventable deaths due to tobacco smoke induced diseases. As a consequence of an increased awareness of smoking-related health risks, heated tobacco products (HTPs) are marketed as reduced toxicant alternatives to conventional tobacco products. Manufacturers claim that levels of toxicants and hazardous compounds are significantly reduced, implying that inhalation of the modified aerosol is less harmful compared to conventional cigarettes. In this manuscript, previous assessments of HTPs are briefly summarized, including a short discussion on challenges with the adaption of standard analytical methods used

Edited by:

Alesia Coralie Ferguson, North Carolina Agricultural and

Technical State University, United States

Reviewed by:

Oscar Camacho,

British American Tobacco, United Kingdom

Florian Martin

Philip Morris International, Switzerland

${ }^{*}$ Correspondence: Nadja Mallock

nadja.mallock@bfr.bund.de for tobacco smoke. The reliability of analytical data is important for risk assessment approaches that are based on reduced toxicant exposure. In order to assess a putative reduction of health risks, an integrated study design is required that should include clinical studies and epidemiology data. One manufacturer applied for a classification as a Modified Risk Tobacco Product (MRTP) in the United States, based on extensive toxicological studies that have also been published. However, data are not yet sufficient for a reliable assessment or recognition of putatively reduced health risks. Challenges regarding a classification in Europe are also discussed briefly in this review.

Keywords: heated tobacco products, emissions, harm reduction, risk assessment, tobacco smoke

\section{INTRODUCTION}

This article was submitted to Environmental Health,

a section of the journal

Frontiers in Public Health

Received: 26 March 2019 Accepted: 20 September 2019 Published: 10 October 2019

Citation:

Mallock N, Pieper E, Hutzler C, Henkler-Stephani F and Luch A (2019) Heated Tobacco Products: A Review of Current Knowledge and Initial Assessments.

Front. Public Health 7:287. doi: 10.3389/fpubh.2019.00287

Although most smokers are aware that tobacco smoking is harmful to their health, it is still the leading cause of premature death worldwide and claims the lives of more than 6 million people every year due to cancer, heart disease, stroke, chronic bronchitis, and emphysema (1-4). A recent study has shown that tobacco smoking increases not only the risk for lung cancer, but also for at least 17 different malignant diseases in humans (5); therefore, successful tobacco control can save millions of lives. With the Framework Convention on Tobacco Control (FCTC), the World Health Organization (WHO) has initiated a comprehensive tobacco control strategy (6). Articles 9 and 10 of the FCTC include specific policy measures to curb tobacco use by regulating the ingredients and the emissions of tobacco products. The overall aim is to decrease toxicity, addictiveness, and appeal to consumers. Parties of this convention have committed themselves to restrict the supply and demand of tobacco products through a wide range of policies and measures. Although FCTC was successfully applied to conventional tobacco products, uncertainties remain on how to cover novel products. In October 2018, Conference of Parties (COP) 8 explicitly proposed to extend the scope of the according legislations to Heated Tobacco Products (HTPs) (7). 
The chemical complexity of cigarette smoke depends on heating conditions inside the lit cigarette. In a conventional cigarette the burning of tobacco leads to combustion at temperatures up to $700-950^{\circ} \mathrm{C}$ during puffs (see Figure 1A). While combustion is limited to the tip of a burning cigarette, pyrolysis and thermal decomposition occur in the oxygen deficient distillation zone. In this part of the cigarette temperatures decrease from 600 to about $200^{\circ} \mathrm{C}$. The majority of smoke toxicants are generated here. Below $350^{\circ} \mathrm{C}$, condensation of less volatile compounds generates a dense aerosol consisting of growing droplets and solid particles (8). As a consequence, cigarette smoke consists of "particulate" and "vapor" phases. The mainstream smoke comprises all constituents inhaled during a puff. One way to reduce the exposure to harmful and potential harmful compounds (HPHCs) in the mainstream smoke of tobacco products is to lower the temperature applied to the tobacco. This approach had previously been tried but could not find acceptance on the market as the technology was not yet advanced $(9,10)$.

Recently, a new generation of HTPs has been introduced to the market which differs widely in product design and temperatures applied to the tobacco. In some devices the tobacco is heated up to $350^{\circ} \mathrm{C}$ via an electrical heating source $(11,12)$ or different sources like carbon (13), whereas in other devices vapor is passed through the tobacco and extracts compounds including flavors and nicotine at lower temperatures $(14,15)$. Three different device designs which are currently present on the market are displayed in Figure 1B. These products contain real tobacco that does not undergo a self-sustaining exothermic combustion.

\section{EMISSIONS}

In accordance with the principle of temperature dependence of HPHC generation in tobacco products, the question of reduced HPHC levels in the emissions was raised. While manufacturers provided the initial studies (15-18), more and more independent investigations have now been published for commercially available products (19-29). These studies were focused on levels of well-known HPHCs in comparison with other tobacco products. Analyzed HPHCs were adopted from the FDA preliminary HPHC list (30) and recommendations by the WHO Study Group on tobacco product regulation (TobReg) (31). Important carcinogens, such as aldehydes and volatile organic compounds, were found to be reduced by about 80 to over $99 \%$ (25). The lowest reduction with only about $80-90 \%$ was reported for acetaldehyde, classified as possibly carcinogenic to humans by the International Agency for Research on Cancer (IARC) (32). Toxicants like tobacco-specific Nnitrosamines (TSNAs), formed primarily during curing and processing of tobacco rather than by combustion, were also present in the filler of HTP consumables. However, compared to cigarette mainstream smoke TSNA levels were reduced by about $80-90 \%$ (20). Metals like cadmium and mercury are taken up by the tobacco plants and are therefore naturally present in products that contain tobacco $(33,34)$. Again, levels were reduced in HTP devices. Whereas cadmium was below detection limit, indicating a reduction of over $99 \%(16,17)$, reduction of mercury was $\sim 75 \%$ as published for one device (17). Polycyclic aromatic hydrocarbons (PAHs) and carbon monoxide are typical products of incomplete combustion. Although reduced by more than $90 \%$, they are still present in HTP emissions (17). Other substances, such as propylene glycol, glycidol, acetol, and 2propen-1-ol have been shown to be elevated in comparison to the combustible reference cigarette in at least one device, due to the higher amount of humectants in the tobacco filler of the HTP consumable (35). Influence on indoor air quality was assessed by the manufacturers and found to be significantly reduced compared to combustible cigarette smoke $(14,36,37)$. Concerns for the use in small and poorly ventilated rooms have been raised by an independent group (38).

Reliability and reproducibility of emission data is a crucial factor for a subsequent risk assessment. To benefit most from the increasing pool of independent studies, a common standard for measurements should be agreed on. The first open question arises regarding the machine puffing protocol. There are different arguments for and against various standard protocols, such as ISO (39) or Health Canada Intense (40). Since some of these devices turn off by themselves after a certain time, a smoking regimen with a higher frequency like HCI can help to collect enough material per consumable to pass thresholds set by the analytical instruments. However, the HCI regime could lead to overestimated reductions, due to blocked filter ventilation in conventional or reference cigarettes. Since this modification results in higher toxicant levels in cigarette smoke, the calculated relative reductions of toxicants in the emissions appear bigger. A new puffing protocol, especially tailored for HTPs, would be possible as well. Importantly, these standard protocols do not mimic average smoking behavior and are not meant to provide a realistic estimate of exposure (41). The purpose of defined smoking regimes is to provide standards to compare key parameters of different products when analyzed in different laboratories. However, recent investigations of the puffing topography $(42,43)$ might suggest further refinements for a better adoption of machine smoking to HTP. ISO/TC126 and CORESTA have started to work on standardized methods.

Since aerosols of HTPs contain a comparatively high proportion of water, standard analytical procedures cannot be easily applied here. Water is trapped on the glass fiber filter and therefore accounts for the total particulate matter (TPM). When the filter is processed further, water loss can occur leading to a reduced analyzed water content. Although not a toxicant, water becomes important when the nicotinefree dried particulate matter, commonly referred to as "tar," is calculated by the subtraction of water and nicotine from TPM (44), though the tobacco industry has developed methods in order to avoid water loss $(45,46)$. When special equipment is required, implementation as a standard method by independent laboratories becomes difficult. Despite these technical challenges, industry and independent laboratories have come to mostly comparable results when using standard procedures that were designed for the analysis of conventional cigarettes. This indicates that these procedures could be a basis for dedicated analytical standards for HTPs. 


\section{A Combustible tobacco cigarette}

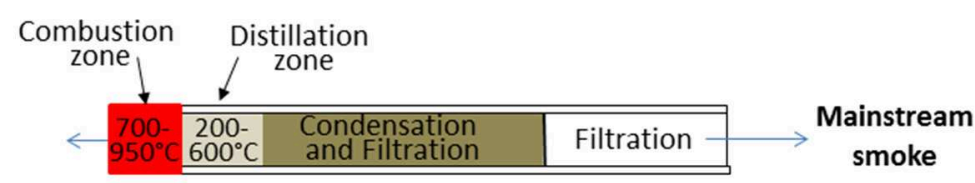

Sidestream smoke

\section{B Different types of Heated Tobacco Products}
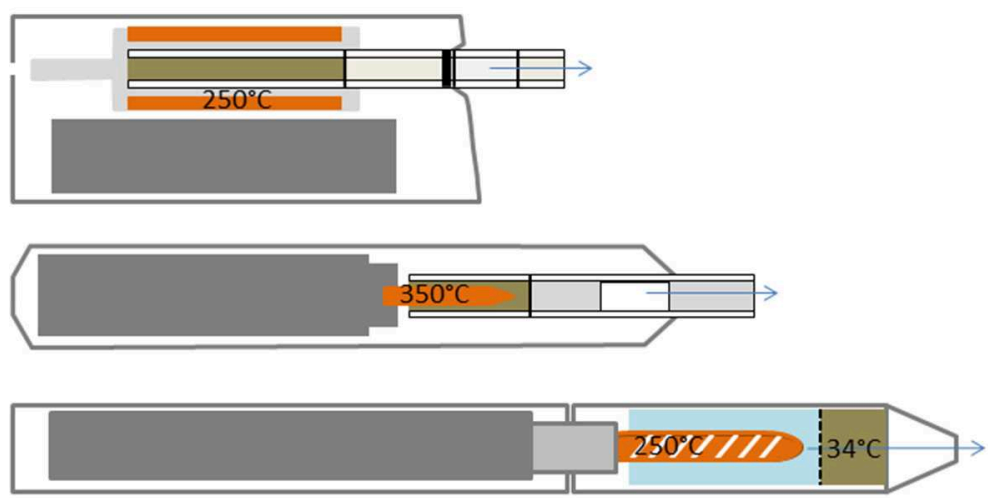

Tobacco $\square$ Heat source $7 / D$ Heating element $\square$ Battery E-Liquid

FIGURE 1 | Temperature zones in a combustible cigarette (A) in comparison to different Heated Tobacco Products (B).

\section{RISK ASSESSMENT APPROACHES}

As discussed, most harmful substances that are known to occur in cigarette mainstream smoke were shown to be lowered by one or two orders of magnitude in HTP emissions. Promoted by the manufacturers, there are discussions if this means a reduction of health risks for HTP consumers followed by controversies whether HTPs can be seen as part of harm reduction strategies. The underlying idea of harm reduction strategies in tobacco control is that the damage caused by tobacco consumption should be at least reduced when it cannot be prevented. Toxicant reduction is not necessarily linked to decreased health risk. Although levels of tar had decreased in combustible cigarettes since the 1950 by nearly two thirds, this was not correlated with corresponding decrease in lung cancer incidences (47). One strategy to assess modified health risks is to compare the tumor potencies of aerosols, as previously applied by Fowles and Dybing to rank the relevant carcinogens and toxicants in cigarette smoke. These calculations are based on individual detection levels in mainstream smoke and on cancer potency factors as indicators of the carcinogenic risk for each smoke constituent (48). The German Federal Institute for Risk Assessment confirmed in its previous study substantially reduced toxicant levels for selected HTPs and provided an initial assessment in 2017 (49). The profound reduction (>99\%) of key carcinogens according to Fowles and Dybing, such as benzene and 1,3-butandien, as well as substantial overall reduction of toxicants is expected to affect health risks, if people abstain completely from other tobacco products. Nicotine levels are still in the range of conventional cigarettes, limiting the risk to switch back to conventional smoking tobacco (25). In a detailed modeling assessment, Stephens compared relative harmfulness of different nicotine products with a model based on exposure data and cancer potencies. The calculated lifetime cancer risk of the HTP, using one data set by the manufacturer, was one to two orders of magnitude lower compared to combustible cigarettes but higher compared to e-cigarettes (50). Lachenmeier et al. calculated the combined margin of exposure (MOE) for the HTP and for combustible cigarettes (51). The obtained ratio between exposure and toxicity effect levels, which could be interpreted as a "safety buffer" (52), was 10-fold higher for the HTP as compared to combustible cigarettes (51). As noted by Stephens, these models only consider toxicants levels and neglect particle effects (50). In addition, there is growing consensus that a complete switch to HTP can reduce toxicant exposure, as confirmed in recent investigations on biomarkers of exposure in smokers (53-57). Haziza et al. reported reductions of 51 to $96 \%$ for selected HPHCrelated biomarkers over a 90-days ambulatory study. However, compliance of participants was decreasing over the ambulatory period, suggesting that relapse to tobacco and/or dual use could counteract potential benefits in real life settings (54). During two 90-days studies, biomarkers of potential harm were additionally assessed $(58,59)$. The results of longer switching studies to 


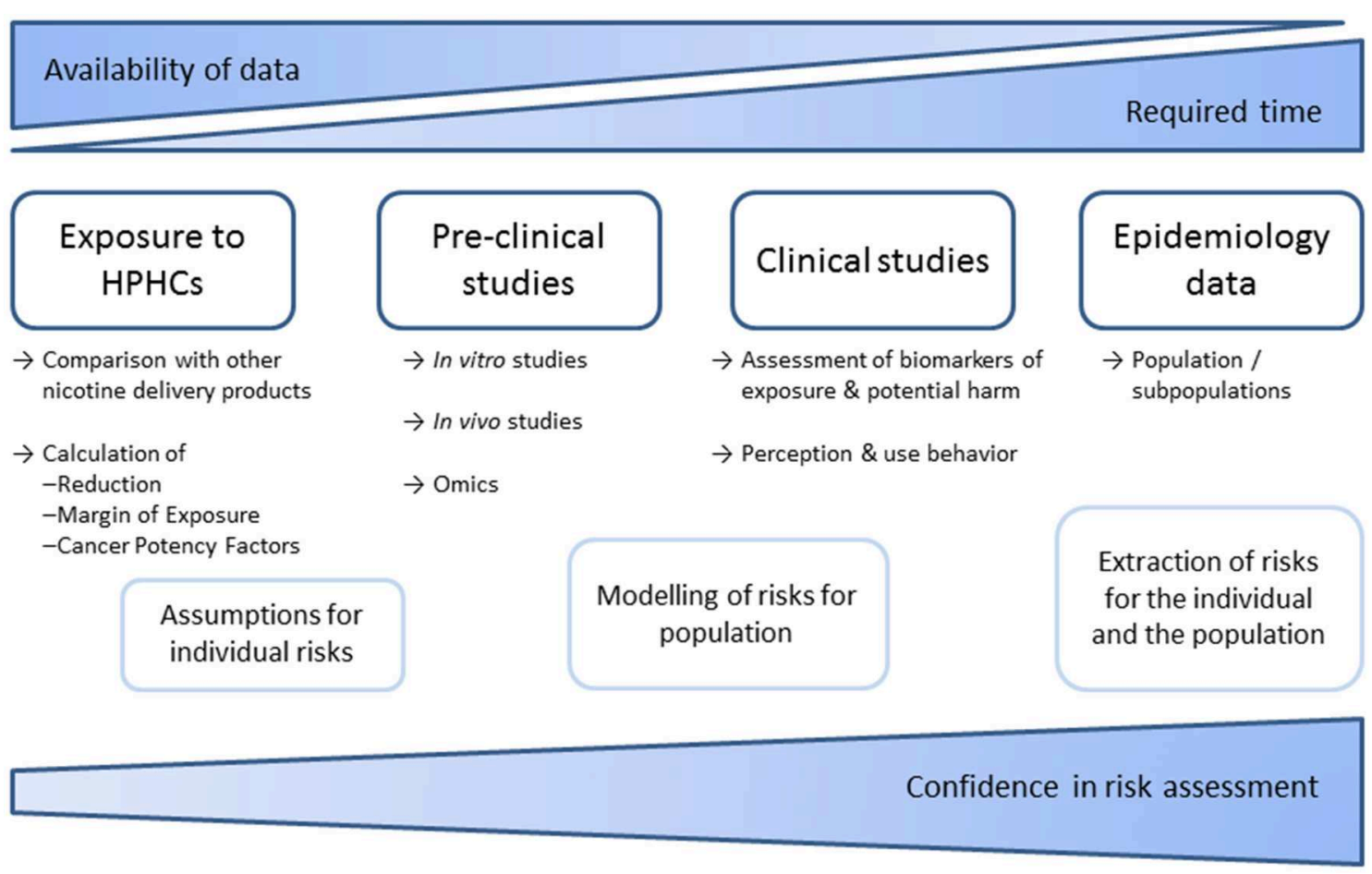

FIGURE 2 | Schematic overview of required data and studies to facilitate risk assessments of tobacco products. Epidemiological data are most conclusive but can usually only be used retrospectively. Therefore, risk assessments rely on models that consider emissions, pre-clinical and clinical studies. Meanwhile numerous studies on smoke chemistry and in vitro toxicology have been published by industry and independent researchers. In contrast, in vivo and clinical studies are far more complex. No sufficient independent data are available.

detect significant reductions of biomarkers of potential harm are anticipated (60).

In the United states, the Family Smoking Prevention and Tobacco Control Act (61) requires tobacco products to not only "significantly reduce harm and the risk of tobacco-related disease to individual tobacco users" but also to "benefit the health of the population as a whole taking into account both users of tobacco products and persons who do not currently use tobacco products" in order to market that product with modified risk claims in the United States. The required scientific evidence for defined claims and additional data that have to be provided by the applicant are described by the FDA in detail in a guidance document (62). Scientific standards for analysis of potential Modified Risks Tobacco Products were also outlined by the Institute of Medicine in 2012 (63). Required data (summarized in Figure 2) include a comprehensive analysis of smoke chemistry (64) as well as data on specified biomarkers of exposure. There is a framework for preclinical studies, proposing in vitro tests of genotoxicity, oxidative stress, and inflammation. The in vitro test battery comprising assays for bacterial mutagenicity, mammalian cytogenetics/mutation, and mammalian cytotoxicity, that has been suggested by a CORESTA task force in 2004 (65), has been conducted by the manufacturers $(17,18,66-70)$. Some in vitro tests can specifically address smoking related adverse effects, as biphasic culture of airway epithelial cells or assays on endothelial activation as conducted by the manufacturers (13,
$71-74)$ and independent researchers $(75,76)$. Further, $3 \mathrm{D}$ in vitro cultured lungs tissues are now available by several commercial suppliers. Consequently, the necessity for animal testing of tobacco products should be questioned, in line with a general shift of focus in modern toxicology (77). In some countries including Germany, animal studies have been prohibited for tobacco products. However, animal studies have been conducted by the tobacco industry (78-81) and independent researchers (82). To address public health questions, population models have been applied (83-86) and publically discussed (87).

In Europe, toxicological assessments of tobacco products are aimed to exclude elevated risks in relation to conventional products, but not to confirm less hazardous product properties. As long as relevant adverse effects cannot be excluded, even modified health risks still remain an issue of concern. In contrast to the United States, products can be placed on the market more easily. Consumers who use these products need to accept all characterized and not yet identified health risks. Also manufacturers might attempt to gain classification as "smokeless tobacco," resulting in less stringent health warnings. In public perception, this could probably be understood as an official acknowledgment of reduced health risks. Such acknowledgment would be premature from the perspective of risk assessment. In the USA, the assessment framework is required to acknowledge reduced/modified risks, if manufacturers can support their claims. Consequently, additional issues, as for example risk 
perception and communication, behavioral assessments of addictiveness or clinical studies (63) need to be considered.

In May 2017, one manufacturer submitted a Modified Risk Tobacco Product Application (MRTPA) for his HTP (88) and in January 2018, the Tobacco Product Scientific Advisory Committee (TPSAC) met to give a recommendation. Due to the lack of human studies, TPSAC was not convinced to support the statement "Scientific studies have shown that switching completely from cigarettes to the IQOS system can reduce the risks of tobaccoreduced diseases," although potential is seen. The relevance of the animal studies to human smokers has been questioned (89). Two 90 -days studies as mentioned above $(58,59)$ did not demonstrate a relevant reduction in biomarkers of potential harm in regard to inflammation and lung function (90). This could also be linked to the continual inhalation of nicotine and remaining toxicants. Reductions of biomarkers of potential harm were also low in the smoking abstinence groups, possibly due to the short study period. Biological relevance needs to be demonstrated with longer exposure studies. However, biomarkers of exposure that have been assessed in various studies were shown to be reduced similarly to cessation level (35), especially markers that are relevant for carcinogenic risks. The less strong claim "Switching completely to IQOS presents less risks of harm than continuing to smoke cigarettes" has therefore been supported by about half of the committee members (89). While the evidence has mostly been seen as strong enough to support a reduced exposure claim, the link to morbidity and mortality has not been seen to be adequately demonstrated (89). The final decision on the MRTPA has not been made by the FDA yet, however the first HTP was authorized in April 2019 for sale, without modified risk status. In Europe, it is widely accepted that current HTPs do not bear additional or other health risks in relation to conventional

\section{REFERENCES}

1. Secretan B, Straif K, Baan R, Grosse Y, El Ghissassi F, Bouvard V, et al. A review of human carcinogens-Part E: tobacco, areca nut, alcohol, coal smoke, and salted fish. Lancet Oncol. (2009) 10:1033-4. doi: 10.1016/S1470-2045(09)70326-2

2. Lim SS, Mokdad AH. Socioeconomic inequalities and infectious disease burden. Lancet. (2012) 379:1080-1. doi: 10.1016/S0140-6736(12)60151-2

3. Pesch B, Kendzia B, Gustavsson P, Jockel KH, Johnen G, Pohlabeln H, et al. Cigarette smoking and lung cancer-relative risk estimates for the major histological types from a pooled analysis of case-control studies. Int J Cancer. (2012) 131:1210-9. doi: 10.1002/ijc.27339

4. Agudo A, Bonet C, Travier N, Gonzalez CA, Vineis P, Bueno-de-Mesquita HB, et al. Impact of cigarette smoking on cancer risk in the European prospective investigation into cancer and nutrition study. J Clin Oncol. (2012) 30:4550-7. doi: 10.1200/JCO.2011.41.0183

5. Alexandrov LB, Ju YS, Haase K, Van Loo P, Martincorena I, Nik-Zainal S, et al. Mutational signatures associated with tobacco smoking in human cancer. Science. (2016) 354:618-22. doi: 10.1126/science.aag0299

6. World-Health-Organization. Work in Progress in Relation to Articles 9 and 10 of the WHO FCTC. Moscow (2014).

7. Conference of the Parties to the WHO Framework Convention on Tobacco Control. FCTC/COP8(22) Novel and Emerging Tobacco Products. (2018). Available online at: https://www.who.int/fctc/cop/sessions/cop8/FCTC_ COP8(22).pdf (accessed September 30, 2019). products. European legislation does not define a modified risk classification. On the contrary, information on the product and package, as well as presentation must not imply reduced hazards compared to any other tobacco product. Although a risk-benefit assessment is required for new tobacco products, permission on the market does not depend on modified risks.

Although a $99 \%$ reduction of some major carcinogens is expected to affect health risks, the magnitude or relevance of such putative reduction is not yet clear. A benefit is likely seen for especially the subset of long-term smokers that are unable to quit or to switch to another nicotine source with less HPHC exposure. However, referring back to the tumor potency models, it should be kept in mind that substantial and relevant health risks are still present. Consequently, HTPs should not be the first option to decrease smoking-associated harm.

\section{AUTHOR CONTRIBUTIONS}

NM prepared the draft manuscript. EP and FH-S contributed sections to the draft. NM, EP, CH, FH-S, and AL created the concept for this article and contributed to manuscript revision and approval of the final version.

\section{FUNDING}

This study was financially supported by intramural funding of the German Federal Institute for Risk Assessment (BfR) (SFP Grant no. 1322-535).

\section{ACKNOWLEDGMENTS}

We thank A. Midha for valuable comments on the manuscript.
8. Baker RR, Bishop LJ. The pyrolysis of tobacco ingredients. J Anal Appl Pyrolysis. (2004) 71:223-331. doi: 10.1016/S0165-2370(03)00090-1

9. Caputi TL. Industry watch: heat-not-burn tobacco products are about to reach their boiling point. Tob Control. (2016) 26:609-10. doi: 10.1136/tobaccocontrol-2016-053264

10. Henkler F, Luch A. Alternativen zu Zigaretten und herkömmlichen Tabakerzeugnissen-Ein kurzer historischer und aktueller Überlick. Rundsch Fleischhygiene Lebensmittelüberwachung. (2015) 67:39-41.

11. Eaton D, Jakaj B, Forster M, Nicol J, Mavropoulou E, Scott K, et al. Assessment of tobacco heating product THP1.0. Part 2: product design, operation and thermophysical characterisation. Regul Toxicol Pharmacol. (2017) 93:4-13. doi: 10.1016/j.yrtph.2017.09.009

12. Smith MR, Clark B, Ludicke F, Schaller JP, Vanscheeuwijck P, Hoeng J, et al. Evaluation of the tobacco heating system 2.2. Part 1: description of the system and the scientific assessment program. Regul Toxicol Pharmacol. (2016) 81(Suppl. 2):S17-26. doi: 10.1016/j.yrtph.2016. 07.006

13. Iskandar AR, Martin F, Leroy P, Schlage WK, Mathis C, Titz B, et al. Comparative biological impacts of an aerosol from carbon-heated tobacco and smoke from cigarettes on human respiratory epithelial cultures: a systems toxicology assessment. Food Chem Toxicol. (2018) 115:109-26. doi: $10.1016 /$ j.fct.2018.02.063

14. Ichitsubo $\mathrm{H}$, Kotaki $\mathrm{M}$. Indoor air quality (IAQ) evaluation of a novel tobacco vapor (NTV) product. Regul Toxicol Pharmacol. (2018) 92:278-94. doi: 10.1016/j.yrtph.2017.12.017 
15. Poynton S, Sutton J, Goodall S, Margham J, Forster M, Scott K, et al. A novel hybrid tobacco product that delivers a tobacco flavour note with vapour aerosol (Part 1): product operation and preliminary aerosol chemistry assessment. Food Chem Toxicol. (2017) 106(Pt A):522-32. doi: 10.1016/j.fct.2017.05.022

16. Forster M, Fiebelkorn S, Yurteri C, Mariner D, Liu C, Wright C, et al. Assessment of novel tobacco heating product THP1.0. Part 3: comprehensive chemical characterisation of harmful and potentially harmful aerosol emissions. Regul Toxicol Pharmacol. (2017) 93:14-33. doi: 10.1016/j.yrtph.2017.10.006

17. Schaller JP, Keller D, Poget L, Pratte P, Kaelin E, McHugh D, et al. Evaluation of the tobacco heating system 2.2. Part 2: chemical composition, genotoxicity, cytotoxicity, and physical properties of the aerosol. Regul Toxicol Pharmacol. (2016) 81(Suppl. 2):S27-47. doi: 10.1016/j.yrtph.2016.10.001

18. Takahashi Y, Kanemaru Y, Fukushima T, Eguchi K, Yoshida S, Miller-Holt J, et al. Chemical analysis and in vitro toxicological evaluation of aerosol from a novel tobacco vapor product: a comparison with cigarette smoke. Regul Toxicol Pharmacol. (2018) 92:94-103. doi: 10.1016/j.yrtph.2017.11.009

19. Auer R, Concha-Lozano N, Jacot-Sadowski I, Cornuz J, Berthet A. Heat-notburn tobacco cigarettes: smoke by any other name. JAMA Intern Med. (2017) 177:1050-2. doi: 10.1001/jamainternmed.2017.1419

20. Bekki K, Inaba Y, Uchiyama S, Kunugita N. Comparison of chemicals in mainstream smoke in heat-not-burn tobacco and combustion cigarettes. $J$ UOEH. (2017) 39:201-7. doi: 10.7888/juoeh.39.201

21. Farsalinos KE, Yannovits N, Sarri T, Voudris V, Poulas K. Nicotine delivery to the aerosol of a heat-not-burn tobacco product: comparison with a tobacco cigarette and e-cigarettes. Nicotine Tob Res. (2018) 20:1004-9. doi: $10.1093 / \mathrm{ntr} / \mathrm{ntx} 138$

22. Farsalinos KE, Yannovits N, Sarri T, Voudris V, Poulas K, Leischow SJ. Carbonyl emissions from a novel heated tobacco product (IQOS): comparison with an e-cigarette and a tobacco cigarette. Addiction. (2018) 113:2099-106. doi: 10.1111/add.14365

23. Leigh NJ, Palumbo MN, Marino AM, O’Connor RJ, Goniewicz ML. Tobacco-specific nitrosamines (TSNA) in heated tobacco product IQOS. Tob Control. (2018) 27(Suppl. 1):s37-8. doi: 10.1136/tobaccocontrol-2018-05 4318

24. Li X, Luo Y, Jiang X, Zhang H, Zhu F, Hu S, et al. Chemical analysis and simulated pyrolysis of tobacco heating system 2.2 compared to conventional cigarettes. Nicotine Tob Res. (2019) 21:111-8. doi: 10.1093/ntr/nty005

25. Mallock N, Boss L, Burk R, Danziger M, Welsch T, Hahn H, et al. Levels of selected analytes in the emissions of "heat not burn" tobacco products that are relevant to assess human health risks. Arch Toxicol. (2018) 92:2145-9. doi: 10.1007/s00204-018-2215-y

26. Simonavicius E, McNeill A, Shahab L, Brose LS. Heat-not-burn tobacco products: a systematic literature review. Tob Control. (2018) 28:582-94. doi: 10.1136/tobaccocontrol-2018-054419

27. Uchiyama S, Noguchi M, Takagi N, Hayashida H, Inaba Y, Ogura H, et al. Simple determination of gaseous and particulate compounds generated from heated tobacco products. Chem Res Toxicol. (2018) 31:585-93. doi: 10.1021/acs.chemrestox.8b00024

28. Ishizaki A, Kataoka H. A sensitive method for the determination of tobacco-specific nitrosamines in mainstream and sidestream smokes of combustion cigarettes and heated tobacco products by online in-tube solid-phase microextraction coupled with liquid chromatographytandem mass spectrometry. Anal Chim Acta. (2019) 1075:98-105. doi: 10.1016/j.aca.2019.04.073

29. Salman R, Talih S, El-Hage R, Haddad C, Karaoghlanian N, El-Hellani A, et al. Free-base and total nicotine, reactive oxygen species, and carbonyl emissions from IQOS, a heated tobacco product. Nicotine Tob Res. (2018) 21:1285-8. doi: $10.1093 /$ ntr/nty235

30. Food and Drug Administration. Harmful and Potentially Harmful Constituents (HPHCs). (2018). Available online at: https://www. fda.gov/tobacco-products/products-ingredients-components/harmful-andpotentially-harmful-constituents-hphcs (accessed September 30, 2019).

31. World Health Organization. WHO Study Group on Tobacco Product Regulation. Report on the scientific basis of tobacco product regulations: fifth report of a WHO Study Group. WHO Technical Report Series, no. 955 (2015). p. 1-234.
32. IARC. Monograph 71, Acetaldehyde. (1999). Available online at: https:// monographs.iarc.fr/wp-content/uploads/2018/06/TR42-12.pdf (accessed September 30, 2019).

33. Chiba M, Masironi R. Toxic and trace elements in tobacco and tobacco smoke. Bull World Health Organ. (1992) 70:269-75

34. Golia EE, Dimirkou A, Mitsios ${ }^{\dagger}$ IK. Heavy-metal concentration in tobacco leaves in relation to their available soil fractions. Commun Soil Sci Plant Anal. (2009) 40:106-20. doi: 10.1080/00103620802623570

35. Food and Drug Administration. FDA Briefing Document: January 2425, 2018 TPSAC Meeting. (2018). Available online at: https://www. fda.gov/downloads/AdvisoryCommittees/CommitteesMeetingMaterials/ TobaccoProductsScientificAdvisoryCommittee/UCM593109.pdf (accessed September 30, 2019).

36. Forster M, McAughey J, Prasad K, Mavropoulou E, Proctor C. Assessment of tobacco heating product THP1.0. Part 4: characterisation of indoor air quality and odour. Regul Toxicol Pharmacol. (2018) 93:34-51. doi: 10.1016/j.yrtph.2017.09.017

37. Mitova MI, Campelos PB, Goujon-Ginglinger CG, Maeder S, Mottier N, Rouget EG, et al. Comparison of the impact of the tobacco heating system 2.2 and a cigarette on indoor air quality. Regul Toxicol Pharmacol. (2016) 80:91-101. doi: 10.1016/j.yrtph.2016.06.005

38. Cancelada L, Sleiman M, Tang X, Russell ML, Montesinos VN, Litter MI, et al. Heated tobacco products: volatile emissions and their predicted impact on indoor air quality. Environ Sci Technol. (2019) 53:7866-76. doi: 10.1021/acs.est.9b02544

39. ISO 3308. Routine Analytical Cigarette-Smoking Machine-Definitions and Standard Conditions. Geneva: International Organisation for Standardisation (2012).

40. Health Canada. Tobacco Reporting Regulations, SOR/2000-273. Ottawa, ON: Government of Canada (2000). Available online at: https://laws-lois.justice.gc. ca/eng/regulations/SOR-2000-273/

41. Hammond D, Wiebel F, Kozlowski LT, Borland R, Cummings KM, O'Connor RJ, et al. Revising the machine smoking regime for cigarette emissions: implications for tobacco control policy. Tob Control. (2007) 16:8-14. doi: 10.1136/tc.2005.015297

42. Zenzen V, Diekmann J, Gerstenberg B, Weber S, Wittke S, Schorp MK. Reduced exposure evaluation of an electrically heated cigarette smoking system. Part 2: smoke chemistry and in vitro toxicological evaluation using smoking regimens reflecting human puffing behavior. Regul Toxicol Pharmacol. (2012) 64(2 Suppl.):S11-34. doi: 10.1016/j.yrtph.2012. 08.004

43. Gee J, Prasad K, Slayford S, Gray A, Nother K, Cunningham A, et al. Assessment of tobacco heating product THP1.0. Part 8: study to determine puffing topography, mouth level exposure and consumption among Japanese users. Regul Toxicol Pharmacol. (2018) 93:84-91. doi: 10.1016/j.yrtph.2017.08.005

44. ISO 4387. Cigarettes - Determination of Total and Nicotine-Free Dry Particulate Matter Using a Routine Analytical Smoking Machine. Geneva: International Organisation for Standardisation (2000).

45. Gasparyan H, Mariner D, Wright C, Nicol J, Murphy J, Liu C, et al. Accurate measurement of main aerosol constituents from heated tobacco products (HTPs): implications for a fundamentally different aerosol. Regul Toxicol Pharmacol. (2018) 99:131-41. doi: 10.1016/j.yrtph.2018.09.016

46. Ghosh D, Jeannet C. An improved Cambridge filter pad extraction methodology to obtain more accurate water and "Tar" values: in situ Cambridge filter pad extraction methodology. Beiträge Tabakforschung Int/Contrib Tob Res. (2014) 26:38-49. doi: 10.2478/cttr-2014-0008

47. Hoffmann D, Hoffmann I, El-Bayoumy K. The less harmful cigarette: a controversial issue. a tribute to Ernst L. Wynder. Chem Res Toxicol. (2001) 14:767-90. doi: 10.1021/tx000260u

48. Fowles J, Dybing E. Application of toxicological risk assessment principles to the chemical constituents of cigarette smoke. Tob Control. (2003) 12:424-30. doi: $10.1136 /$ tc. 12.4 .424

49. German Federal Institute for Risk Assessment (BfR). Vorläufige Risikobewertung von Tobacco Heating-Systemen als Tabakprodukte. (2017). Available online at: https://mobil.bfr.bund.de/cm/343/vorlaeufigerisikobewertung-von-tobacco-heating-systemen-als-tabakprodukte.pdf (accessed September 30, 2019). 
50. Stephens WE. Comparing the cancer potencies of emissions from vapourised nicotine products including e-cigarettes with those of tobacco smoke. Tob Control. (2018) 27:10-17. doi: 10.1136/tobaccocontrol-2017-053808

51. Lachenmeier DW, Anderson P, Rehm J. Heat-not-burn tobacco products: the devil in disguise or a considerable risk reduction? Int J Alcohol Drug Res. (2018) 7:8-11. doi: 10.7895/ijadr.250

52. EPA. Framework Manual EPA-748-B12-001 13. Quantitative Risk Assessment Calculations. (2012). Available online at: https://www.epa.gov/sites/ production/files/2015-05/documents/13.pdf (accessed September 30, 2019).

53. Gale N, McEwan M, Eldridge AC, Fearon IM, Sherwood N, Bowen $\mathrm{E}$, et al. Changes in biomarkers of exposure on switching from a conventional cigarette to tobacco heating products: a randomized, controlled study in healthy Japanese subjects. Nicotine Tob Res. (2018) 21:1220-7. doi: 10.1093/ntr/nty104

54. Haziza C, de La Bourdonnaye G, Donelli A, Poux V, Skiada D, Weitkunat $\mathrm{R}$, et al. Reduction in exposure to selected harmful and potentially harmful constituents approaching those observed upon smoking abstinence in smokers switching to the menthol tobacco heating system 2.2 for three months (Part 1). Nicotine Tob Res. (2018) 2:161-72. doi: 10.1093/ntr/ntz013

55. Haziza C, de La Bourdonnaye G, Skiada D, Ancerewicz J, Baker G, Picavet P, et al. Evaluation of the tobacco heating system 2.2. Part 8: 5-day randomized reduced exposure clinical study in Poland. Regul Toxicol Pharmacol. (2016) 81(Suppl. 2):S139-50. doi: 10.1016/j.yrtph.2016.1 1.003

56. Ludicke F, Picavet P, Baker G, Haziza C, Poux V, Lama N, et al. Effects of switching to the tobacco heating system 2.2 menthol, smoking abstinence, or continued cigarette smoking on biomarkers of exposure: a randomized, controlled, open-label, multicenter study in sequential confinement and ambulatory settings (Part 1). Nicotine Tob Res. (2018) 20:161-72. doi: 10.1093/ntr/ntw287

57. Miura N, Yuki D, Minami N, Kakehi A, Futamura Y. A study to investigate changes in the levels of biomarkers of exposure to selected cigarette smoke constituents in Japanese adult male smokers who switched to a non-combustion inhaler type of tobacco product. Regul Toxicol Pharmacol. (2015) 71:498-506. doi: 10.1016/j.yrtph.2015. 02.007

58. Haziza C, de La Bourdonnaye G, Donelli A, Skiada D, Poux V, Weitkunat $\mathrm{R}$, et al. Favorable changes in biomarkers of potential harm to reduce the adverse health effects of smoking in smokers switching to the menthol tobacco heating system 2.2 for three months (Part 2). Nicotine Tob Res. (2019). doi: 10.1093/ntr/ntz084. [Epub ahead of print].

59. Ludicke F, Picavet P, Baker G, Haziza C, Poux V, Lama N, et al. Effects of switching to the menthol tobacco heating system 2.2, smoking abstinence, or continued cigarette smoking on clinically relevant risk markers: a randomized, controlled, open-label, multicenter study in sequential confinement and ambulatory settings (Part 2). Nicotine Tob Res. (2018) 20:173-82. doi: 10.1093/ntr/ntx028

60. Newland N, Lowe FJ, Camacho OM, McEwan M, Gale N, Ebajemito J, et al. Evaluating the effects of switching from cigarette smoking to using a heated tobacco product on health effect indicators in healthy subjects: study protocol for a randomized controlled trial. Intern Emerg Med. (2019) 14:885-98. doi: 10.1007/s11739-019-02090-8

61. United States Public Laws. Family Smoking Prevention and Tobacco Control Act (FSPTCA) Pub. L. 111-31, 21 U.S.C. 387 Et Seq. (2009). Available online at: https://www.govinfo.gov/content/pkg/PLAW-111publ31/ pdf/PLAW-111publ31.pdf (accessed September 30, 2019).

62. U.S. Food \& Drug Administration. Modified Risk Tobacco Product Applications: Draft Guidance for Industry. (2012). Available online at: https://www.fda.gov/downloads/TobaccoProducts/Labeling/ RulesRegulationsGuidance/UCM297751.pdf (accessed September 30, 2019).

63. IOM (Institute of Medicine). Scientific Standards for Studies on Modified Risk Tobacco Products. Washington, DC: The National Academies Press (2012).

64. Food and Drug Administration. Harmful and Potentially Harmful Constituents in Tobacco Products and Tobacco Smoke; Established List. (2012). Available online at: https://www.govinfo.gov/content/pkg/FR-201204-03/pdf/2012-7727.pdf

65. CORESTA. The Rationale and Strategy for Conducting In Vitro Toxicology Testing of Tobacco Smoke. (2004). Available online at: https://www.coresta.
org/sites/default/files/technical_documents/main/IVT_TF_Rationale-IVTTesting-Tob.-Smoke_Report_Jun04.pdf (accessed September 30, 2019).

66. Jaunky T, Adamson J, Santopietro S, Terry A, Thorne D, Breheny D, et al. Assessment of tobacco heating product THP1.0. Part 5: in vitro dosimetric and cytotoxic assessment. Regul Toxicol Pharmacol. (2018) 93:5261. doi: 10.1016/j.yrtph.2017.09.016

67. Taylor M, Jaunky T, Hewitt K, Breheny D, Lowe F, Fearon IM, et al. A comparative assessment of e-cigarette aerosols and cigarette smoke on in vitro endothelial cell migration. Toxicol Lett. (2017) 277:123-8. doi: 10.1016/j.toxlet.2017.06.001

68. Taylor M, Thorne D, Carr T, Breheny D, Walker P, Proctor C, et al. Assessment of novel tobacco heating product THP1.0. Part 6: a comparative in vitro study using contemporary screening approaches. Regul Toxicol Pharmacol. (2018) 93:62-70. doi: 10.1016/j.yrtph.2017.08.016

69. Thorne D, Breheny D, Proctor C, Gaca M. Assessment of novel tobacco heating product THP1.0. Part 7: comparative in vitro toxicological evaluation. Regul Toxicol Pharmacol. (2018) 93:71-83. doi: 10.1016/j.yrtph.2017.08.017

70. Thorne D, Leverette R, Breheny D, Lloyd M, McEnaney S, Whitwell J, et al. Genotoxicity evaluation of tobacco and nicotine delivery products: Part two. In vitro micronucleus assay. Food Chem Toxicol. (2019) 132:110546. doi: 10.1016/j.fct.2019.05.054

71. Kogel U, Gonzalez Suarez I, Xiang Y, Dossin E, Guy PA, Mathis C, et al. Biological impact of cigarette smoke compared to an aerosol produced from a prototypic modified risk tobacco product on normal human bronchial epithelial cells. Toxicol In Vitro. (2015) 29:2102-15. doi: 10.1016/j.tiv.2015.08.004

72. van der Toorn M, Sewer A, Marescotti D, Johne S, Baumer K, Bornand D, et al. The biological effects of long-term exposure of human bronchial epithelial cells to total particulate matter from a candidate modified-risk tobacco product. Toxicol In Vitro. (2018) 50:95-108. doi: 10.1016/j.tiv.2018.02.019

73. Marescotti D, Gonzalez Suarez I, Acali S, Johne S, Laurent A, Frentzel S, et al. High Content screening analysis to evaluate the toxicological effects of harmful and potentially harmful constituents (HPHC). J Vis Exp. (2016) 111:53987. doi: 10.3791/53987

74. Iskandar AR, Titz B, Sewer A, Leroy P, Schneider T, Zanetti F, et al. Systems toxicology meta-analysis of in vitro assessment studies: biological impact of a candidate modified-risk tobacco product aerosol compared with cigarette smoke on human organotypic cultures of the aerodigestive tract. Toxicol Res. (2017) 6:631-53. doi: 10.1039/C7TX00047B

75. Leigh NJ, Tran PL, O'Connor RJ, Goniewicz ML. Cytotoxic effects of heated tobacco products (HTP) on human bronchial epithelial cells. Tob Control. (2018) 27(Suppl. 1):s26-9. doi: 10.1136/tobaccocontrol-2018-054317

76. Sohal SS, Eapen MS, Naidu VGM, Sharma P. IQOS exposure impairs human airway cell homeostasis: direct comparison with traditional cigarette and e-cigarette. ERJ Open Res. (2019) 5:00159-2018. doi: 10.1183/23120541.00159-2018

77. Krewski D, Acosta D Jr, Andersen M, Anderson H, Bailar JC III, Boekelheide $\mathrm{K}$, et al. Toxicity testing in the 21 st century: a vision and a strategy. J Toxicol Environ Health B Crit Rev. (2010) 13:51-138. doi: 10.1080/10937404.2010.483176

78. Kogel U, Schlage WK, Martin F, Xiang Y, Ansari S, Leroy P, et al. A 28day rat inhalation study with an integrated molecular toxicology endpoint demonstrates reduced exposure effects for a prototypic modified risk tobacco product compared with conventional cigarettes. Food Chem Toxicol. (2014) 68:204-17. doi: 10.1016/j.fct.2014.02.034

79. Phillips B, Veljkovic E, Boue S, Schlage WK, Vuillaume G, Martin F, et al. An 8-month systems toxicology inhalation/cessation study in $\mathrm{Apoe}^{-/-}$mice to investigate cardiovascular and respiratory exposure effects of a candidate modified risk tobacco product, THS 2.2, compared with conventional cigarettes. Toxicol Sci. (2016) 149:411-32. doi: 10.1093/toxsci/kfv243

80. Phillips B, Veljkovic E, Peck MJ, Buettner A, Elamin A, Guedj E, et al. A 7-month cigarette smoke inhalation study in C57BL/6 mice demonstrates reduced lung inflammation and emphysema following smoking cessation or aerosol exposure from a prototypic modified risk tobacco product. Food Chem Toxicol. (2015) 80:328-45. doi: 10.1016/j.fct.2015.03.009

81. Phillips BW, Schlage WK, Titz B, Kogel U, Sciuscio D, Martin F, et al. A 90day OECD TG 413 rat inhalation study with systems toxicology endpoints demonstrates reduced exposure effects of the aerosol from the carbon heated 
tobacco product version 1.2 (CHTP1.2) compared with cigarette smoke. I. Inhalation exposure, clinical pathology and histopathology. Food Chem Toxicol. (2018) 116(Pt B):388-413. doi: 10.1016/j.fct.2018.04.015

82. Nabavizadeh P, Liu J, Havel CM, Ibrahim S, Derakhshandeh R, Jacob Iii P, et al. Vascular endothelial function is impaired by aerosol from a single IQOS HeatStick to the same extent as by cigarette smoke. Tob Control. (2018) 27(Suppl. 1):s13-9. doi: 10.1136/tobaccocontrol-2018-054325

83. Djurdjevic S, Sponsiello-Wang Z, Lee PN, Fry JS, Weitkunat R, Ludicke F, et al. Modeling the impact of changes in tobacco use on individual disease risks. Regul Toxicol Pharmacol. (2018) 97:88-97. doi: 10.1016/j.yrtph.2018.06.001

84. Lee PN, Fry JS, Hamling JF, Sponsiello-Wang Z, Baker G, Weitkunat R. Estimating the effect of differing assumptions on the population health impact of introducing a reduced risk tobacco product in the USA. Regul Toxicol Pharmacol. (2017) 88:192-213. doi: 10.1016/j.yrtph.2017.06.009

85. Martin F, Vuillaume G, Baker G, Sponsiello-Wang Z, Ricci PF, Ludicke F, et al. Quantifying the risk-reduction potential of new modified risk tobacco products. Regul Toxicol Pharmacol. (2018) 92:358-69. doi: 10.1016/j.yrtph.2017.12.011

86. Weitkunat R, Lee PN, Baker G, Sponsiello-Wang Z, Gonzalez-Zuloeta Ladd AM, Ludicke F. A novel approach to assess the population health impact of introducing a modified risk tobacco product. Regul Toxicol Pharmacol. (2015) 72:87-93. doi: 10.1016/j.yrtph.2015.03.011

87. Max WB, Sung HY, Lightwood J, Wang Y, Yao T. Modelling the impact of a new tobacco product: review of Philip Morris International's Population Health Impact Model as applied to the IQOS heated tobacco product. Tob Control. (2018) 27(Suppl. 1):s82-6. doi: 10.1136/tobaccocontrol-2018-054572
88. U.S. Food \& Drug Administration. Philip Morris Products S.A. Modified Risk Tobacco Product (MRTP) Applications. (2018). Available online at: https://www.fda.gov/TobaccoProducts/Labeling/MarketingandAdvertising/ ucm546281.htm (accessed September 30, 2019).

89. Tobacco Product Scientific Advisory Committee. Meeting Transcript. (2018). Available online at: https://www.fda.gov/ downloads/AdvisoryCommittees/CommitteesMeetingMaterials/ TobaccoProductsScientificAdvisoryCommittee/UCM599235.pdf (accessed September 30, 2019).

90. Glantz SA. PMI's own in vivo clinical data on biomarkers of potential harm in Americans show that IQOS is not detectably different from conventional cigarettes. Tob Control. (2018) 27(Suppl. 1):s9-12. doi: 10.1136/tobaccocontrol-2018054413

Conflict of Interest: The authors declare that the research was conducted in the absence of any commercial or financial relationships that could be construed as a potential conflict of interest.

Copyright (c) 2019 Mallock, Pieper, Hutzler, Henkler-Stephani and Luch. This is an open-access article distributed under the terms of the Creative Commons Attribution License (CC BY). The use, distribution or reproduction in other forums is permitted, provided the original author(s) and the copyright owner(s) are credited and that the original publication in this journal is cited, in accordance with accepted academic practice. No use, distribution or reproduction is permitted which does not comply with these terms. 